Editorial

\title{
Immunosuppression in Kidney Transplantation
}

Maurizio Salvadori ${ }^{1,}{ }^{*}$, Aris Tsalouchos ${ }^{2}$

1. Department of Renal Transplantation, Careggi University Hospital, viale Pieraccini 18 , 50139 Florence, Italy; E-Mail: maurizio.salvadori1@gmail.com

2. Aris Tsalouchos Nephrology and Dialysis Unit, Saints Cosmas and Damian Hospital, Via Cesare Battisti, 2-51017 Pescia (PT), Italy; E-Mail:aris.tsalouchos@gmail.com

* Correspondence: Maurizio Salvadori; E-Mail: maurizio.salvadori1@gmail.com

Special Issue: Immunosuppression in Kidney Transplantation

\section{OBM Transplantation}

2020, volume 4, issue 1

doi:10.21926/obm.transplant.2001097
Received: January 19, 2020

Accepted: January 19, 2020

Published: February 03, 2020

\begin{abstract}
Immunosuppressive therapy in renal transplantation is divided into two phases as induction and maintenance therapy. Induction therapy is an intense immunosuppressive therapy administered at the time of kidney transplantation to reduce the risk of acute allograft rejection. In general, induction immunosuppressive strategies utilized by kidney transplant centers fall in one of the two categories. One approach relies upon high doses of conventional immunosuppressive agents, while the other uses antibodies directed against Tcell antigens with lower doses of conventional agents. Maintenance immunosuppressive therapy is administered to almost all kidney transplant recipients to help prevent acute rejection and the loss of renal allograft. Although an adequate level of immunosuppression is required to dampen the immune response, the level of chronic immunosuppression is decreased over time (as the risk of acute rejection decreases) to help lower the overall risk of infection and malignancy; these risks directly correlate with the degree of overall immunosuppression. However, the optimal maintenance immunosuppressive therapy in kidney transplantation is not established. The major immunosuppressive agents that are available in various combination regimens are glucocorticoids (primarilyoral prednisone), azathioprine, mycophenolate mofetil (MMF), enteric-coated
\end{abstract}

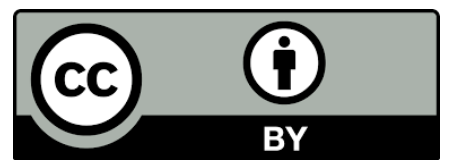

(C)2020 by the author. This is an open access article distributed under the conditions of the Creative Commons by Attribution License, which permits unrestricted use, distribution, and reproduction in any mediumor format, provided the original work is correctly cited. 
mycophenolate sodium (EC-MPS), cyclosporine (unmodified or modified [micro emulsion] form), tacrolimus, everolimus, rapamycin (sirolimus), and belatacept.

\section{Keywords}

Induction therapy; maintenance therapy; mechanisms of action; side effects; calcineurin inhibitors

\section{Introduction}

The immunosuppressant drugs used in renal transplantation are distinguished into two categories, based on the time of use, as induction therapy and maintenance therapy. A different classification distinguishes drugs based on their use to control acute cellular rejection (TCMR) and acute antibody rejection (ABMR).

\section{Induction Therapy}

Induction therapy is administered at the time of transplantation to reduce the risks of acute rejection. These drugs are classified into two categories or strategies. One strategy consists of the use of high doses of the same drugs used for maintenance therapy. A different and more frequently used strategy consists of the use of mono or polyclonal antibodies directed against the T-cell antigens. Monoclonal antibodies against T-cell activation have also been used. Many controlled studies documented that induction therapy with mono or polyclonal antibodies is more efficient than induction therapy with high doses of maintenance drugs [1]. The antibodies used in the induction therapy are anti-lymphocyte antibodies or antibodies against the interleukin 2 receptor (IL-2R).

\subsection{Antilymphocyte Antibodies}

The antibodies may be polyclonal or monoclonal. The polyclonal antibodies (rATG) obtained from the rabbit are used more frequently. The monoclonal antibody includes Alemtuzumab (Campath 1-H), a humanized antibody against CD-52 [2]. Rituximab is a monoclonal antibody against CD20, which induces B-cell depletion. It is used more frequently in the post-transplant treatment of acute rejection, but also in induction therapy in the transplantation of ABOincompatible pairs or recipients with preformed antibodies against the HLA system of the donor [3].

\subsection{Antibodies against IL-2R}

T-cell proliferation after transplantation is linked to IL-2 production. Thus, monoclonal antibodies against IL-2R are used in induction therapy [4]. Patients are stratified for high-risk and low-risk acute rejection to select a better induction therapy. 


\subsubsection{High-Risk Acute Rejection}

This category belongs to patients with more mismatches for the HLA antigens, high levels of anti-HLA antigens, ABO-incompatibility, or antibodies directed against the donor HLA antigens. These patients are administered with 1 or $2 \mathrm{mg} / \mathrm{kg}$ rATG during the transplant. The administration is often repeated for several days post-transplant along with maintenance therapy. Several studies have documented the higher efficacy of rATG administration compared to no rATG [5]. Other studies recorded the higher efficacy of rATG administration compared to anti-IL-2R [6].

Generally, rATG is administrated at doses ranging from 1 to $6 \mathrm{mg}$ and repeated for up to ten days. Induction therapy with a total dose of $6 \mathrm{mg} / \mathrm{kg}$ was found to be optimal [7]. A higher or extended period of doses is related to a high risk of infectious diseases or lymphoproliferative disorders. Alemtuzumab (Campath $1-\mathrm{H}$ ) as an induction therapy is not frequently used ( $10 \%$ of transplantations in the USA). Moreover, comparative studies on Alemtuzumab efficacy versus rATG or anti-IL-2R did not show a clear superiority. A systematic review of 21 studies documented that Rituximab is beneficial in the cases of $A B O$ incompatibility, while not in the case of antibodies against donor HLA.

\subsubsection{Low-Risk Acute Rejection}

These patients may have induction either with RATG or with antibodies against IL-2R. The Kidney Disease: Improving Global Outcomes KDIGO (2009) recommends the use of antibodies against IL-2R as the first-line therapy in low-risk patients [8]. Anti-IL-2R antibodies are administered at $20 \mathrm{mg}$ during transplantation and repeated in the fourth day after transplantation. Some studies advocate rATG superiority, but other studies do not confirm it for low-risk patients.

A systematic review by Cochrane analyzed 71 randomized controlled studies [9] that reported the efficacy of anti-IL-2R. In placebo-controlled studies, IL-2R inhibitors were found to reduce the incidence of acute rejection. Compared to rATG, IL-2R antibodies have a higher acute rejection incidence, but fewer side effects like infections and malignancies.

\section{Maintenance Therapy}

Maintenance therapy is administered lifelong in all transplant patients to avoid both acute and chronic rejection with subsequent organ loss. An adequate level of maintenance therapy is necessary to reduce immune activation in the recipient. After a long period of post-transplantation, a safe reduction of maintenance therapy may also be attempted to reduce the side effects. Drugs most frequently used in the maintenance therapy are steroids, antimetabolite drugs (azathioprine, mycophenolate mofetil [MMF], sodium mycophenolate enteric coated [EC-MPS]), calcineurin inhibitors (cyclosporine [CyA] and tacrolimus [TAC]), the inhibitors of mammalian target of Rapamycin (mTOR) (sirolimus and everolimus) and, more recently, Belatacept. 


\subsection{Mechanism of Action of Immunosuppressant Drugs}

\subsubsection{Corticosteroids}

Corticosteroids modulate the immune response by regulating the gene expression related to several molecules, such as IL-1, IL-2, interferon-gamma (IFN- - ), tumor necrosis factor-alpha (TNF$\alpha)$, and IL-6.

\subsubsection{Azathioprine}

Azathioprine inhibits purine synthesis and, subsequently, RNA synthesis. It also reduces lymphocyte proliferationin addition to the number of monocytes and granulocytes and thus inhibits the promyelocyte proliferation in the bone marrow.

\subsubsection{MMF and EC-MPS}

In almost all transplant centers, MMF and EC-MPS have been replaced by azathioprine. Mycophenolic acid is a selective inhibitor of the denovo pathway of purine synthesis. It also inhibits inosine monophosphate dehydrogenase and selectively inhibits B and T cell proliferation.

\subsubsection{Cyclosporine}

Cyclosporine inhibits calcineurin after binding to cyclophilin. As a result, the gene expression of cytokines produced by T-cells is blocked, principally, IL-2, IL-3, IL-4, IFN- $\gamma$, and TNF- $\alpha$. In particular, IL-2 reduction lowers the immune response.

\subsubsection{Tacrolimus}

The mechanism of action is similar to cyclosporine with calcineurin inhibition. Although completely different, it does not bind to cyclophilin, but to a different molecule called FK506binding protein (FKBP). Moreover, the side effects of TAC are similar to that of CyA, but with several differences.

\subsection{6 mTOR Inhibitors}

Sirolimus and everolimus are the primary drugs belonging to this group. They bind to the complex mTOR and inhibit p70S6 kinase phosphorylation and the pathway mediated by IL-2. Additionally, mTOR inhibitors are a powerful inhibitor of vascular endothelial growth factor (VEGF). In several studies, mTOR inhibitors have been used to reduce or completely withdraw the calcineurin inhibitors.

\subsubsection{Belatacept}

Belatacept minimizescardiovascular risk and nephrotoxicity related to calcineurin inhibitors. T-cell stimulation needs a double signal. The first signal is represented by the interaction of HLA antigens and the T-cell receptor (TCR). Multiple stimuli represent the second signal. The most important is 
the interaction between CD28 on the T-cell and CD80 on the antigen-presenting cell (APC) (Figure 1). Belatacept acts as a competitive antagonist, binding to CD80 and inhibiting CD28 stimulation.

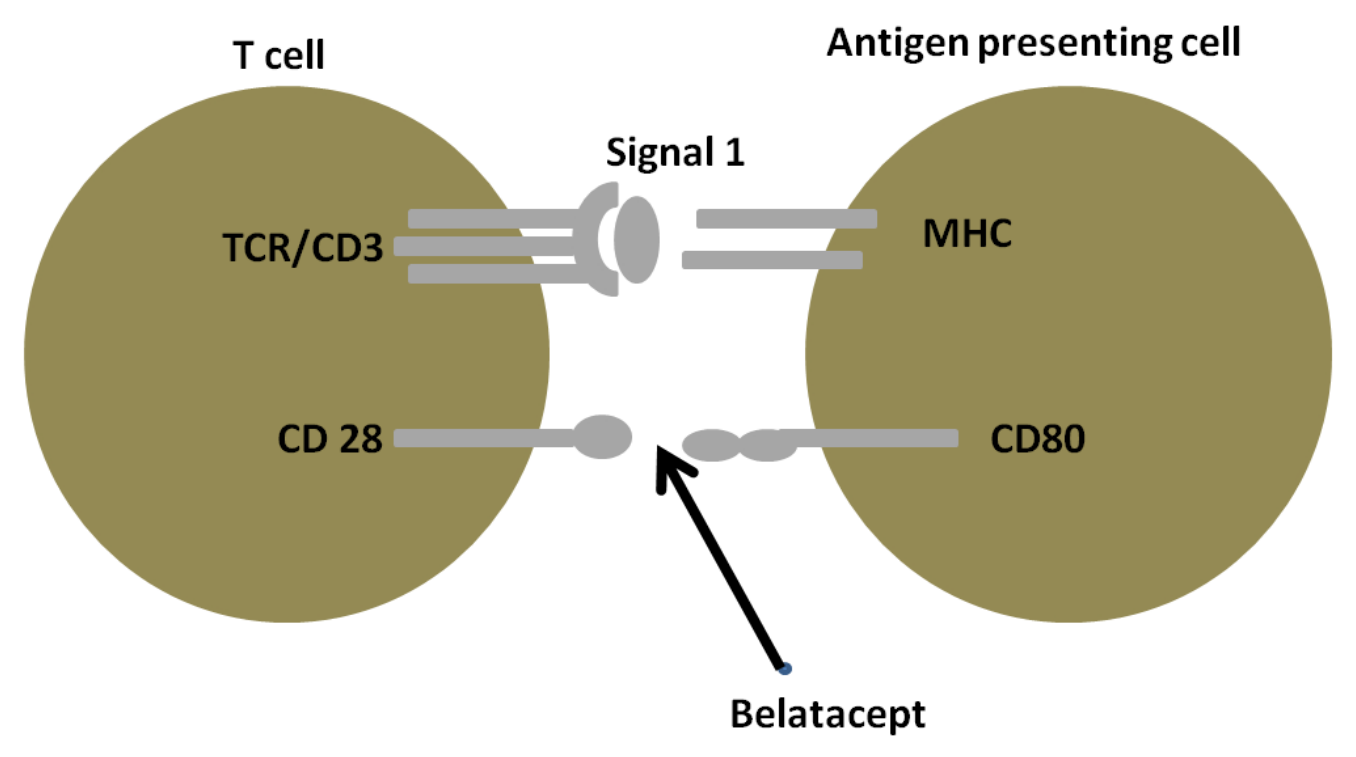

Figure $1 \mathrm{~T}$-cell activation through two signals.

\subsection{Criteria for Administration of Maintenance Therapy}

The majority of transplant centers use maintenance therapy with three drugs, according to KDIGO guidelines [2].

- A calcineurin inhibitor (CyA or TAC)

- An antimetabolite drug (Azathioprine, MMF or EC-MPS)

- Corticosteroids

Although good results have been attained by several authors, mTOR inhibitors, in initial maintenance therapy, are not preferred by all. The majority of transplant centers prefer to use mTOR inhibitors in the case of nephrotoxicity related to calcineur in inhibitors. Maintenance therapy starts at the time of transplantation. EC-MPS is often given before transplantation, followed by a dose of $360 \mathrm{mg}$ twice a day.

Steroids are administrated during the transplant often before reanastomosis intravenously at the dose of $500 \mathrm{mg} / 1 \mathrm{~g}$ and followed by decreasing the dosage up to 5-10 $\mathrm{mg}$ one month after transplantation. The calcineurin inhibitor (TAC) starts the first day after transplantation at the dose of $0.08 \mathrm{mg} / \mathrm{kg} /$ diet till the trough level reaches $7-10 \mathrm{mg} / \mathrm{mL}$ one month after transplantation. In the case of delayed kidney function soon after transplantation, several centers delay the calcineurin inhibitors until creatinine is decreased.

\subsection{Choice of the Calcineurin Inhibitor}

CYA and TAC have a similar action, although the choice of TAC is more frequent. In a metaanalysis performed in 2005 [10], TAC significantly reduced the acute rejection incidence with respect to CyA. These data have also been confirmed by the Symphony study [11]. However, major side effects of TAC are neurological disorders, higher incidence of post-transplant diabetes 
mellitus and alopecia, while major side effects CyA are hirsutism, gum hyperplasia, and hypertension.

Both drugs interact with several other drugs. Higher levels of TAC or CyA in blood have been observed with the administration of nicardipine derived calcium blockers, anti-mycotic drugs and antibiotics like erythromycin. In contrast, lower levels have been observed in the case of antiepileptic or anti-tuberculosis drugs.

The use of mTOR inhibitors to reduce the dosage of calcineurin inhibitors showed good results in several European studies [12]. However, a review from Cochrane [13] did not conclude on this strategy.

\subsection{Choice of an Anti-Metabolite Drugs}

Azathioprine has been completely substituted by MMF or EC-MPS, as documented in several studies. Additionally, severe side effects like leucopenia are observed with azathioprine.

\subsection{Steroid Decrease or Withdrawal}

Several transplant centers decrease the steroid administration up to it reaches $5 \mathrm{mg} /$ day. The KDIGO guidelines suggest the possibility of safe steroid withdrawal to avoid their side effects at least in low-risk patients. However, this strategy is debatable. Steroid withdrawal could prevent the side effects but favor the incidence of late acute rejection. The steroid withdrawal should be decided individually based on the immunological risk, renal function, and the severity of the steroid-related side effects.

\subsection{Belatacept}

Several studies have evaluated the efficacy and safety of Belatacept. While this drug blocks the second co-stimulation signalit does allow to do not administer the calcineurin inhibitors, avoiding their side effects. In the study BENEFIT [14], patients treated with Belatacept had a higher incidence of acute rejection at 1-year than CyA but a better renal function that persisted up to seven years after transplantation. These data were confirmed by the study BENEFIT-EXT in which marginal donors were used [15]. A problem common to both studies was a higher incidence of lymphoproliferative disorders in patients on treatment with Belatacept, principally in patients with no protection against the Epstein-Barr virus.

\section{Treatment of T Cell-Mediated Acute Rejection (TCMR)}

In the majority of patients with grade $1 \mathrm{~A}$ or $1 \mathrm{~B}$ TCMR, intravenous boluses of methylprednisolone $(500 \mathrm{mg}$ ) repeated up to 3-5 times control the rejection. It is often necessary to increase the level of maintenance therapy. In patients with TCMR grade 1B, in the first period after transplantation, the use of rATG added to the steroids is preferred [16]. In patients with acute rejection, grade II or III, in addition to steroid boluses, administration of rATG at the doses of $1.5-3 \mathrm{mg} / \mathrm{kg}$ up to a total dosage of $5-10 \mathrm{mg} / \mathrm{kg}$ is often necessary. In the case of patients who cannot receive rATG because of allergy to rabbit proteins, it is possible to administer a single intravenous bolus of $30 \mathrm{mg}$ Alemtuzumab [17]. Besides, in all patients treated with rATG or Alemtuzumab, anantimicrobial and antivirus prophylaxis is mandatory. 


\section{Treatment of Acute Rejection Antibody-Mediated (ABMR)}

$A B M R$ is a severe condition that often leads to graft loss and hence requires aggressive treatment. The removal of antibodies from the blood is done by plasmapheresis or immunoadsorption. Several drugs are needed to be added, and many of which represent a therapeutic approach for the future.

\subsection{Intravenous Immunoglobulin (IVIG)}

The intravenous infusion of $2 \mathrm{~g} / \mathrm{kg}$ immunoglobulin leads to a high level of IgG in the blood that interferes with the Fc receptors on antigen-presenting cells. Additionally, the binding of IgG to FcgRllb receptors on B lymphocytes and plasma cells leads to their apoptosis. Further immunomodulation of high doses of IgG is related to their capacity for favoring the development of T regulatory cells [18].

\subsection{Rituximab}

Rituximab is a monoclonal antibody against the antigen CD20 on lymphocytes. It is a depleting agent that leads to the elimination of $B$ cells by complement-mediated cytotoxicity (ADCC) or by apoptosis after binding to CD20 [18]. To date, rituximab has been used in several protocols of desensitization in the case of transplants of HLA incompatibles [19] and to control ABMR itself [19] Additionally, rituximab associated with plasmapheresis and IVIG can reduce the risk of antibodymediated chronic rejection (AMCR) [20].

\subsection{Bortezomib}

Bortezomib, a proteasome inhibitor, initially approved for the treatment of multiple myelomareduces the activity of NF-kB, cell proliferation and induces cell apoptosis [21]. In the treatment of $A B M R$, bortezomib was proved to be effective, especially in the treatment of early acute rejections [22].

\subsection{Eculizumab}

Eculizumab is a humanized monoclonal antibody that binds to the complement $\mathrm{C} 5$ and inhibits the generation of $\mathrm{C} 5 \mathrm{a}$ and the membrane attack complex (MAC), C5b-C9.In renal transplantation, eculizumab has been used in the treatment of ABMR in association with plasmapheresis and IVIG [23].

\subsection{Drugs for the Future}

Most of the drugs shown in Table 1 are promising for the treatment of ABMR. Many of them act by depleting B-cells or plasma cells. They are humanized monoclonal antibodies, anti-CD20 or CD19, which include ocrelizumab, ofatumumab, and veltuzumab. MDX 1342 acts on B19 on the plasma cell surface while epratuzumab acts on CD22. Belimumab acts on cytokines or cytokine receptors in particular against BAFF (B-cell activating factor) that causes B-cell activation and differentiation. IL- 6 is a powerful activator of B-cells and plasma cells. Tocilizumab acts against the 
IL-6 receptor. In addition to eculizumab, another monoclonal antibody is rhC1NH that blocks C1. So far, only a single study has evaluated rhC1NH in treating patients with ABMR [24].

Table 1 Drugs for the future.

\begin{tabular}{|c|c|c|c|c|}
\hline Category & Drug & Molecule & Molecular target & Cellular target \\
\hline \multirow{5}{*}{$\begin{array}{l}\text { Drugs depleting } \\
\text { Iymphocytes B }\end{array}$} & Ocrelizumab & $\begin{array}{l}\text { Monoclonal } \\
\text { antibody } \\
\text { humanized }\end{array}$ & CD20 & $\begin{array}{c}\text { Mature and } \\
\text { "naïve" } \\
\text { lymphocyte B }\end{array}$ \\
\hline & Ofatumumab & $\begin{array}{l}\text { Monoclonal } \\
\text { antibody } \\
\text { humanized }\end{array}$ & $\mathrm{CD} 20$ & $\begin{array}{l}\text { Mature and } \\
\text { "naïve" } \\
\text { lymphocyte B }\end{array}$ \\
\hline & Veltuzumab & $\begin{array}{l}\text { Monoclonal } \\
\text { antibody } \\
\text { humanized }\end{array}$ & CD20 & $\begin{array}{l}\text { Mature and } \\
\text { "naïve" } \\
\text { lymphocyte B }\end{array}$ \\
\hline & MDX 1342 & $\begin{array}{l}\text { Monoclonal } \\
\text { antibody } \\
\text { humanized }\end{array}$ & CD19 & $\begin{array}{l}\text { Lymphocyte } B \\
\text { and plasma cell }\end{array}$ \\
\hline & Epratuzumab & $\begin{array}{c}\text { Monoclonal } \\
\text { antibody } \\
\text { humanized }\end{array}$ & $\mathrm{CD} 22$ & $\begin{array}{l}\text { Lymphocyte B } \\
\text { "naïve" }\end{array}$ \\
\hline \multirow[t]{2}{*}{$\begin{array}{l}\text { Drug } \\
\text { anticytokines }\end{array}$} & Belimumab & $\begin{array}{l}\text { Monoclonal } \\
\text { antibody } \\
\text { humanized }\end{array}$ & BAFF & \\
\hline & Tocilizumab & $\begin{array}{l}\text { Monoclonal } \\
\text { antibody } \\
\text { humanized }\end{array}$ & IL-6 & \\
\hline \multirow[t]{2}{*}{$\begin{array}{l}\text { Drugs acting on } \\
\text { the complement }\end{array}$} & RhC1NH & $\begin{array}{l}\text { Human } \\
\text { recombinant } \\
\text { inhibitor }\end{array}$ & Factor C1 & \\
\hline & Eculizumab & $\begin{array}{l}\text { Monoclonal } \\
\text { antibody } \\
\text { humanized }\end{array}$ & Factor C5 & \\
\hline
\end{tabular}

\section{Author Contributions}

Salvadori M wrote the Editorial; Tsalouchos A helped in find literature data and the corrected references. Both authors reviewed the final form of the manuscript. 


\section{Competing Interests}

The authors have declared that no competing interests exist.

\section{References}

1. Cai J, Terasaki PI. Induction immunosuppression improves long-term graft and patient outcome in organ transplantation: An analysis of United Network for Organ Sharing registry data. Transplantation. 2010; 90: 1511-1515.

2. Morris PJ, Russell NK. Alemtuzumab (Campath-1H): A systematic review in organ transplantation. Transplantation. 2006; 81: 1361-1367.

3. van den Hoogen MW, Kamburova EG, Baas MC, Steenbergen EJ, Florquin S, M Koenen HJ, et al. Rituximab as induction therapy after renal transplantation: A randomized, double-blind, placebo-controlled study of efficacy and safety. Am J Transplant. 2015; 15: 407-416.

4. Vincenti F, Kirkman R, Light S, Bumgardner G, Pescovitz M, Halloran P, et al. Interleukin-2receptor blockade with daclizumab to prevent acute rejection in renal transplantation. Daclizumab Triple Therapy Study Group. N Engl J Med. 1998; 338: 161-165.

5. Mourad G, Garrigue V, Squifflet JP, Besse T, Berthoux F, Alamartine E, et al. Induction versus noninduction in renal transplant recipients with tacrolimus-based immunosuppression. Transplantation. 2001; 72: 1050-1055.

6. Brennan DC, Daller JA, Lake KD, Cibrik D, Del Castillo D. Rabbit antithymocyte globulin versus basiliximab in renal transplantation. N Engl J Med. 2006; 355: 1967-1977.

7. Wong W, Agrawal N, Pascual M, Anderson DC, Hirsch HH, Fujimoto K, et al. Comparison of two dosages of thymoglobulin used as a short-course for induction in kidney transplantation. Transpl Int. 2006; 19: 629-635.

8. Kidney Disease: Improving Global Outcomes (KDIGO) Transplant Work Group. KDIGO clinical practice guidline for the care of kidney transplant recipients. Am J Transplant. 2009; 9: S1.

9. Webster AC, Ruster LP, McGee R, Matheson SL, Higgins GY, Willis NS, et al. Interleukin 2 receptor antagonists for kidney transplant recipients. Cochrane Database Syst Rev. 2010; CD003897.

10. Webster AC, Woodroffe RC, Taylor RS, Chapman JR, Craig JC. Tacrolimus versus ciclosporin as primary immunosuppression for kidney transplant recipients: Meta-analysis and metaregression of randomised trial data. BMJ. 2005; 331: 810.

11. Ekberg H, Tedesco-Silva H, Demirbas A, Vítko S, Nashan B, Gürkan A, et al. Reduced exposure to calcineurin inhibitors in renal transplantation. N Engl J Med. 2007; 357: 2562-2575.

12. Pascual J, Berger SP, Witzke O, Tedesco H, Mulgaonkar S, Qazi Y, et al. Everolimus with reduced calcineurin inhibitor exposure in renal transplantation. J Am Soc Nephrol. 2018; 29: 1979-1991.

13. Webster AC, Lee VW, Chapman JR, Craig JC. Target of rapamycin inhibitors (sirolimus and everolimus) for primary immunosuppression of kidney transplant recipients: A systematic review and meta-analysis of randomized trials. Transplantation. 2006; 81: 1234-1248.

14. Vincenti F, Charpentier B, Vanrenterghem Y, Rostaing L, Bresnahan B, Darji P, et al. A phase III study of belatacept-based immunosuppression regimens versus cyclosporine in renal transplant recipients (BENEFIT study). Am J Transplant. 2010; 10: 535-546. 
15. Durrbach A, Pestana JM, Pearson T, Vincenti F, Garcia VD, Campistol J, et al. A phase III study of belatacept versus cyclosporine in kidney transplants from extended criteria donors (BENEFIT-EXT study). Am J Transplant. 2010; 10: 547-557.

16. Minervini MI, Torbenson M, Scantlebury V, Vivas $C$, Jordan $M$, Shapiro $R$, et al. Acute renal allograft rejection with severe tubulitis (Banff 1997 grade IB). Am J Surg Pathol. 2000; 24: 553558.

17. Boothpur R, Hardinger KL, Skelton RM, Lluka B, Koch MJ, Miller BW, et al. Serum sickness after treatment with rabbit antithymocyte globulin in kidney transplant recipients with previous rabbit exposure. Am J Kidney Dis. 2010; 55: 141-143.

18. Jordan SC, Kahwaji J, Toyoda M, Vo A. B-cell immunotherapeutics: Emerging roles in solid organ transplantation. Curr Opin Organ Transplant. 2011; 16: 416-424.

19. Becker YT, Becker BN, Pirsch JD, Sollinger HW. Rituximab as treatment for refractory kidney transplant rejection. Am J Transplant. 2004; 4: 996-1001.

20. Loupy A, Suberbielle-Boissel C, Zuber J, Anglicheau D, Timsit MO, Martinez F, et al. Combined posttransplant prophylactic IVIg/anti-CD 20/plasmapheresis in kidney recipients with preformed donor-specific antibodies: A pilot study. Transplantation. 2010; 89: 1403-1410.

21. Lemy A, Toungouz $M$, Abramowicz D. Bortezomib: A new player in pre- and post-transplant desensitization? Nephrol Dial Transplant. 2010; 25: 3480-3489.

22. Walsh RC, Everly JJ, Brailey P, Rike AH, Arend LJ, Mogilishetty G, et al. Proteasome inhibitorbased primary therapy for antibody-mediated renal allograft rejection. Transplantation. 2010; 89: $277-284$.

23. Locke JE, Magro CM, Singer AL, Segev DL, Haas M, Hillel AT, et al. The use of antibody to complement protein $\mathrm{C} 5$ for salvage treatment of severe antibody-mediated rejection. Am J Transplant. 2009; 9: 231-235.

24. Tillou X, Poirier N, Le Bas Bernardet S. Recombinant human C1- inhibitor prevents acute antibody-mediated rejection in alloimmunized baboons. Kidney Int. 2010; 78: 152-159.

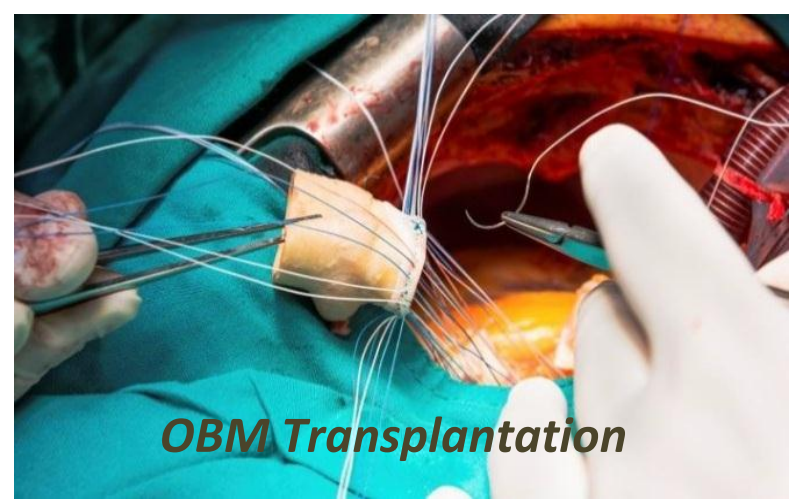

Enjoy OBM Transplantationby:

1. Submitting a manuscript

2. Joining in volunteer reviewer bank

3. Joining Editorial Board

4. Guest editing a special issue

For more details, please visit: http://www.lidsen.com/journals/transplantation 